Article

\title{
Contested Architecture: The 'Woba' Residential Colony in Basel, 1930
}

\author{
Rhea Rieben \\ Department of History, University of Basel, 4051 Basel, Switzerland; E-Mail: rhea.rieben@unibas.ch
}

Submitted: 31 March 2019 | Accepted: 25 June 2019 | Published: 30 September 2019

\begin{abstract}
In 1930, a housing exhibition called 'Woba' took place in the city of Basel. Unique for Switzerland, the commercial aspect of the furniture industry was complemented by a newly constructed residential colony. In accordance with discussions held one year before at the II CIAM congress in Frankfurt a. M., the Wohnung für das Existenzminimum was brought to life. Thirteen architectural offices experimented with different spatial designs in order to develop cheap and hygienic housing for the working class. For one month, some of the houses were open to the public. In the Swiss press, a vivid and controversial debate arose. On one side, its supporters advocated for standardized and rationalized housing as an appropriate way of living for modern individuals. On the other side, conservative forces saw a communist scheme at work in this housing in the style of Neues Bauen. By analyzing contemporary press articles on the Woba, this paper shows that the question of society's future was being negotiated through architecture and furniture.
\end{abstract}

\section{Keywords}

anti-communism; Baubolschewismus; Hans Schmidt; minimal housing; modern society; Neues Bauen; social engineering; sociology of architecture; Typenmöbel; Woba

\section{Issue}

This article is part of the issue "Housing Builds Cities", edited by Luca Ortelli (École Polytechnique Fédérale de Lausanne, Switzerland), Chiara Monterumisi (École Polytechnique Fédérale de Lausanne, Switzerland) and Alessandro Porotto (École Polytechnique Fédérale de Lausanne, Switzerland).

(C) 2019 by the author; licensee Cogitatio (Lisbon, Portugal). This article is licensed under a Creative Commons Attribution 4.0 International License (CC BY).

\section{Introduction}

We are on Im Surinam, a long, straight street in a flatroofed residential area at the rear of a railway station on the outskirts of Basel. A lively scene unfolds in front of us. Walls are being repainted, furniture moved around, curtains installed-even an old electric Therma stove has been set up in the kitchen. Entering through the garden, we pass a small shed on the left, and find ourselves right in the middle of the kitchen as we step into the house. Doors lead to bathtub and laundry room, and the modestly furnished living room. It is surprisingly bright for a back-to-back house, even though there is only one large window in the living room. The two bedrooms and small toilet on the upper floor are equally flooded with light, illuminated from above by a carefully placed skylight. We search in vain for wall cupboards or storage space. There is just enough room for the essentials: a bed, a chair, a table, a cupboard. The house is small, very small. A 45-m2 home for a family with two children, including a garden (Figures 1 and 2). It was built in 1930 by Paul Artaria and Hans Schmidt as part of a housing exhibition colony. Today it is inhabited again, and yet open to the public as a museum house, equipped with the original furniture (www.ein-haus-woba.ch).

The small size of this house is programmatic, a prototype for the "low-priced working-class apartment" (Baukommission der Schweizer Wohnungsausstellung Basel 1930, 1929, p. 1). Most working families of the late 1920s lived in poor conditions, crammed together in damp, narrow rooms with little light and ventilation. Hygienists and doctors voiced increasing concerns about such living conditions, and the pressing housing shortage after the First World War prompted a new generation of architects to design a new, better kind of home for the masses. The Eglisee residential colony, which our house on Im Surinam is part of, is one of but a few of these projects which actually came to fruition in Switzerland. 
Although the street's name evokes images of exotic lands in distant countries, and could give grounds for speculations about exoticizing the flat-roof settlement, the street was formerly called Gotterbarmweg and only renamed in 1941 (Schnetzler, 2005).

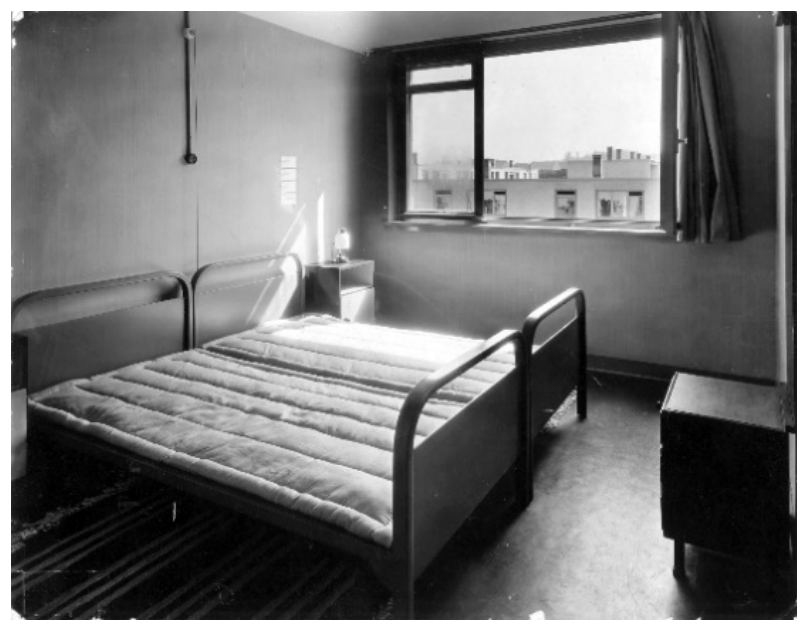

Figure 1. The 'Woba' Residential Colony Eglisee, 1930. Block 8, Artaria \& Schmidt Architects. Bedroom, upper floor. Source: Spreng (1930).

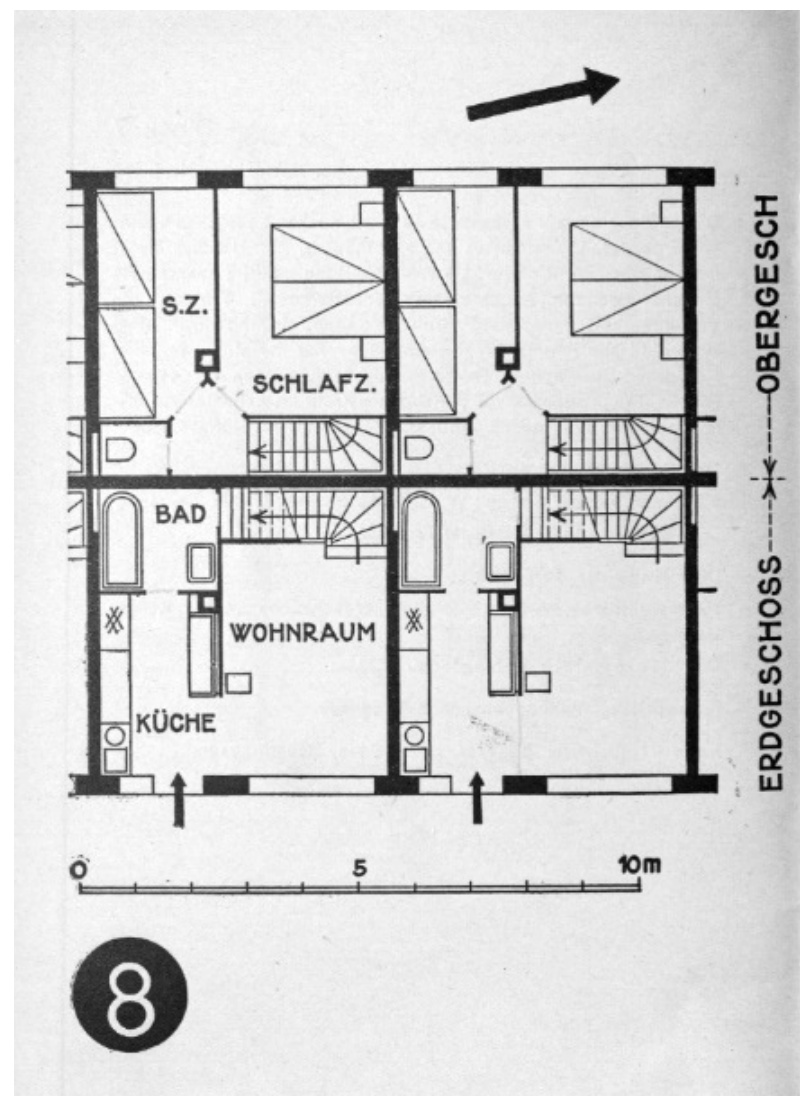

Figure 2. Floor plan, block 8. Source: Woba (1930, p. 20).

Construction management for the Eglisee housing project was taken over by the Basel architect August Künzel, who had completed neighbouring cooperative housing projects together with Hans Bernoulli, an important Basel-based architect and city planner. The realization of the Eglisee residential colony marked the endpoint of a larger urban development project of the Hirzbrunnen area on the outskirts of Basel (Mooser, 2000; Pola \& Frischknecht, n.d.; Wohnbaugenossenschaften Nordwestschweiz, 2012). During the heyday of the cooperative housing movement in interwar Basel, around 250 houses were built in garden city fashion by Bernoulli and Künzel-all of them with steep roofs. It was only in 1928 when Hans Schmidt and Paul Artaria took over Hans Bernoulli's position as co-planners of the housing cooperative's Lange Erlen and Rüttibrunnen that the flat roof first appeared in Basel's residential areas (Figure 3; Artaria \& Schmidt Architekten, 1928; Pläne der Wohngenossenschaften Lange Erlen, 1928).

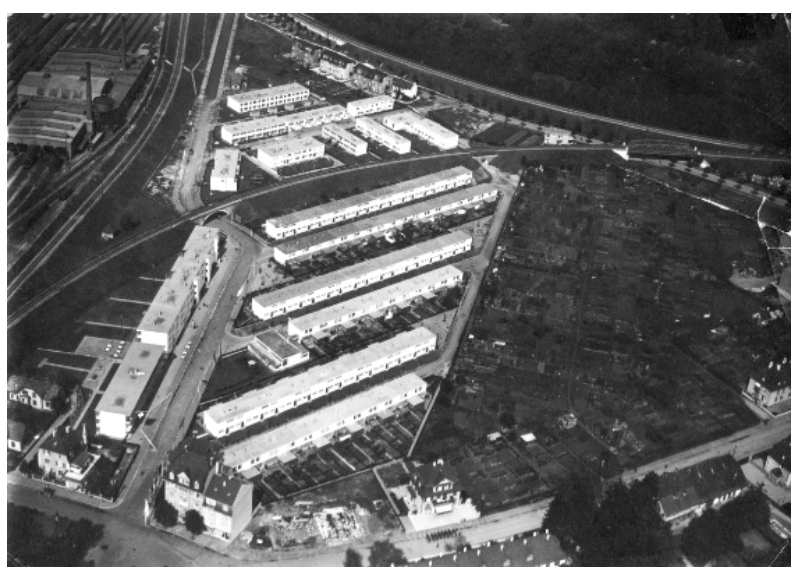

Figure 3. Siedlung Schorenmatten, 1929, and WOBASiedlung Eglisee, 1930 ("Siedlung Schorenmatten," 1930).

In comparison to the earlier cooperative housing projects, it is worth taking a closer look at the Eglisee settlement as a special case for two reasons. Firstly, the Eglisee residential colony was complemented by an apartment exhibition in the halls of the Mustermesse Basel called 'Woba', short for Schweizerische Wohnungsausstellung Basel, which, in addition to showcasing the latest trends in Swiss furniture design, also dealt with historical, statistical and scientific aspects of Swiss housing. Visitors were invited to compare completely furnished rooms tailored to the individual needs of the potential resident, such as the apartment for "The Time Conscious" or "The Growing Family". A makeshift Woba-Hotel, complete with restaurant, bar and a dancing hall, presenting the latest achievements in the hotel business was set up during the four weeks of the exhibition. Secondly, the designs of the permanent housing were considered as experimental and therefore developed by several Swiss architects. The idea was to compare different room layouts and examine their advantages and disadvantages. Thirteen architectural firms were invited to submit designs for an apartment building with three to four storeys, a two-storey single-family house, and a two- 
family house (Figures 4 and 5). Basements for the houses were optional, the flat roof mandatory (Baukommission der Schweizer Wohnungsausstellung Basel 1930, 1929, p. 2). The apartment building was supposed to contain around 50 two or three-room apartments and the terraced houses about 70 flats, each with its own bathroom and laundry facilities. The total construction costs were not to exceed 15,000 Swiss francs (Baukommission der Schweizer Wohnungsausstellung Basel 1930, n.d., p. 2) because different housing solutions were wanted for low-income groups.

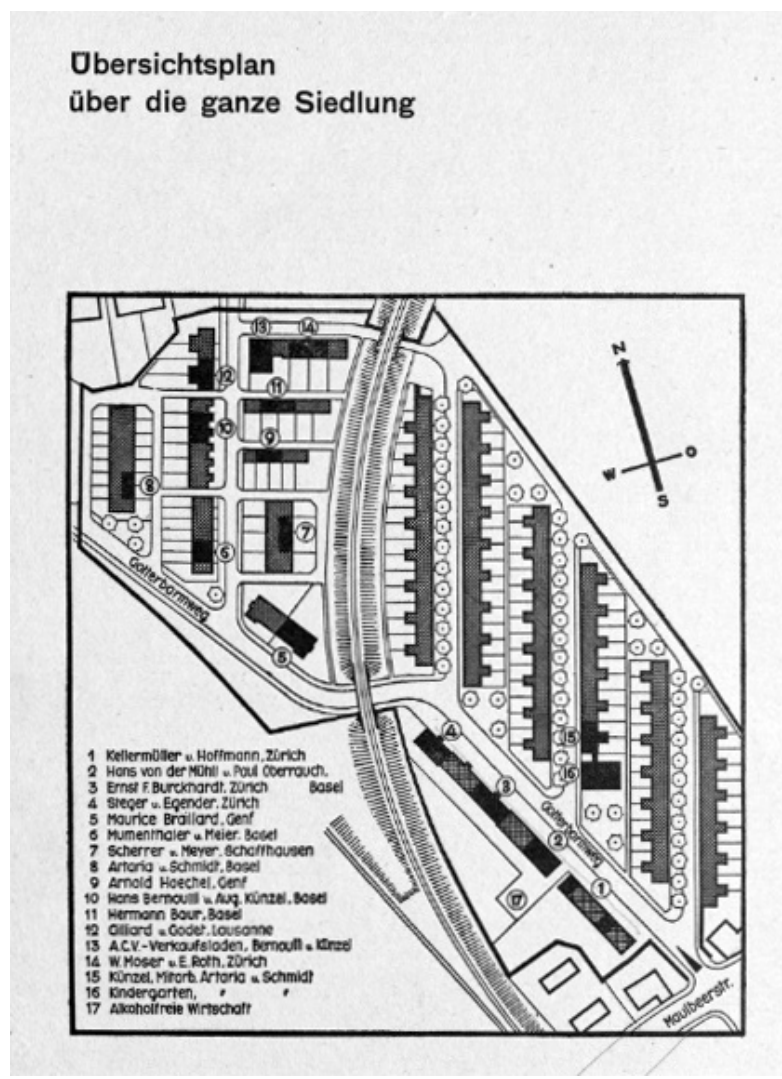

Figure 4. Situation plan of the Woba residential colony. Source: Woba (1930, p. 1).

The idea for the 'Woba' was first conceived in 1926 and envisioned as a commercially oriented exhibition that would highlight the dynamism of the Swiss furniture industry (Gruntz, 2016, 2017). The local government agreed to support such an exhibition, and invited Hermann Kienzle, Director of the Gewerbemuseum in Basel and representative of the Schweizerischer Werkbund (SWB) to draw up a concept. Kienzle's position quickly became clear. In accordance with SWB guidelines, he criticized the furniture industry, which above all, would produce cheaply produced items and decorate them with ornaments in order to sell a bookshelf to people who perhaps did not have more than four books. Kienzle thought that:

These new simple construction methods and rising manufacturing costs should go hand in hand with a simplification of the furniture. For [artists and architects], furniture is not a showpiece, but a commodity. The comfort and homeliness of a room does not depend solely on the furniture or even on a single beautiful piece, but on the practical design and arrangement of a room.... Today we know the problem of the new home is not merely an artistic one, but just as much a technical, economic and socio-ethical one. (Kienzle, 1926, pp. 3-4, 7-8.)

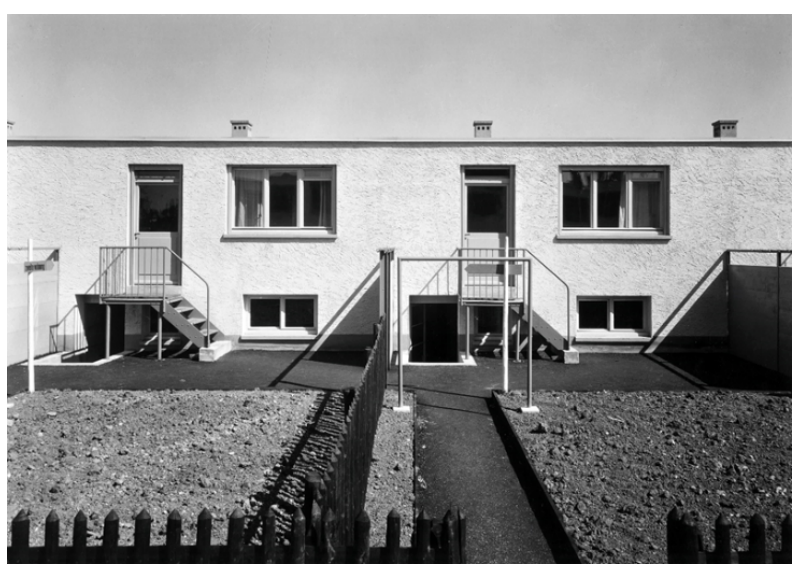

Figure 5. The 'WOBA' Residential Colony Eglisee, 1930. Block 10, Hans Bernoulli, August Künzel. From the garden. Source: Ochs-Walde (1930).

A modern approach, Kienzle proposed, would require furniture to be exhibited in real living situations. By referring to the Weissenhofsiedlung by the Deutscher Werkbund (DWB) in Stuttgart, Kienzle concluded that an exhibition as proposed by the management of the Mustermesse could merely satisfy the commercial interests of the industry. If solutions for a modern form of housing and living were to be sought, then the exhibition at the Mustermesse would need to be supplemented by a real apartment, built especially for this purpose (Kienzle, 1926, p. 8). Thus, the idea of a residential colony was born.

\section{International Context}

The Eglisee project should be placed in a larger context, where the exhibition in Stuttgart 1927 can be taken as a starting point. During the 1920s, in a series of exhibitions in Zurich's Kunstgewerbemuseum, the topic of adequate living and furnishing was introduced to the Swiss public. It was the exhibition Das Neue Heim (The new Home, in 1926), which laid the groundworks for Swiss involvement in the Werkbundsiedlung in Germany in 1927. The success of the Zurich exhibition prompted the DWB to invite a group of Swiss architects to design the furniture and interior of six apartments for Mies van der Rohe's house in Stuttgart in 1927 (Bürkle \& Eidgenössische Technische Hochschule Zürich, 1994). Based on Weissenhof in Stuttgart, further housing exhibition projects by national associations of craftsmen rapidly developed not only in Switzerland with 
Eglisee and Neubühl (1928-1932), but in Brno (in 1928), Wroctaw (in 1928), Prague (in 1932) and Vienna (in 1932). An important element seems to be the personal connection between the Swiss avant-garde and the project in Germany: seven of Eglisee's architects were part of the 1927 exhibition. Besides, the architecture collective for the Neubühl project in Zurich, which is far better known than the Eglisee housing colony due to Sigfried Giedion's active promotion in the international architecture scene (Marbach \& Rüegg, 1990), was formed during the work on the Stuttgart exhibition. These architects, taking part in both projects, were at the forefront of the Swiss avant-garde and well connected with international modernist architects.

Swiss architects were also actively engaged in the Congrès Internationaux d'Architecture Moderne (CIAM). Since 1928, modernist architects had gathered at CIAM in order to find solutions for modern housing and city planning. Rudolf Steiger, Werner Max Moser and Hans Schmidt, who worked both on the Eglisee and Neubühl projects, were founding members of CIAM. The architects of various European countries gathering at CIAM thought of themselves as an international movement and sought to coordinate their efforts across national borders. The same year the Eglisee project took off, the II CIAM Congress entitled Die Wohnung für das Existenzminimum took place in Frankfurt am Main. CIAM members discussed sociological and biological aspects of housing for the working poor and developed models on how to solve this construction task. As the experience of the Stuttgart exhibition has shown, concentrating merely on new construction methods and materials would not reduce the construction costs to a sufficient minimum. The solution would be the rationalization of the living space (Schmidt, 1930a). Therefore, a touring exhibition was opened in parallel with the congress, which exhibited floor plans of various housing in European cities, including our house Im Surinam, providing the public with feasible solutions. The exhibition also found its way to Basel in 1929. The 'Woba' was therefore the practical realization of a much-discussed theoretical problem among European avant-garde architects. This assumption is underlined by the fact that Basel architect Hans Schmidt (1893-1972), who presented a clear construction schedule for the Eglisee residential colony, played a crucial role both at CIAM and the 'Woba' (Steinmann, 1979, pp. 35-71). Schmidt was a pioneer of the so-called Neues Bauen in Switzerland, and, together with his office partner Paul Artaria, had been experimenting with various materials and construction methods for several years. Schmidt's basic idea for creating affordable housing for low-income groups was, in accordance with the CIAM conclusions, to concentrate on small living units. The smaller the flat, Schmidt contended, the lower its costs. Yet Schmidt and his colleagues did not simply seek to reduce the size of the standard flat, but to develop a completely new type of flat, an entirely new housing concept (Schmidt, 1965).
For modern architects, the problem of minimal apartments was not just a matter of design, but of social responsibility. The living unit-the Ration 'Wohnung'was to satisfy the "minimal biological and sociological demands of the residents" (Schmidt, 1929, p. 51). "A more compact and at the same time more appropriate layout of the floor plan", Schmidt argued, "changes in the use and size of rooms, and more sensible furnishings make the apartment cheaper without making it worse. On the contrary-saving space saves work" (Schmidt, n.d., p. 3). Typification, rationalization and standardization were key principles for the design of both flats and furniture. This was not just due to ideological or programmatic concerns, but had a practical dimension: conventional furniture was far too bulky for these small apartments. In a series of essays entitled "City and Apartment", appearing in the Basler National-Zeitung between February and October 1930 on Schmidt's initiative, he stated as follows: "Are you shocked by the small size of the bedrooms? Please-we've abolished the washstand with marble top and divided the three-part mirror cabinet into two small type-cabinets" (Schmidt, 1930b). A new form of living also required a new kind of furniture.

Behind the discussion on minimal housing, the size of apartments and the right kind of furniture, a much larger discourse loomed. Divergent concepts of individuality, personality and family and especially of the role of women in family and household clashed in these debates. Below, I will show how the question of society's future form was being negotiated through architecture. These debates can be reconstructed from articles of over three hundred Swiss newspapers collected by the 'Woba' office between 1929 and 1930. As my analysis proves, the debates were not only influenced by the architects themselves, but discussed by the general public. These most vivid and emotional reactions to the 'Woba' residential colony reflect that through the questions of new housing concepts for the masses, political discussions and fears were being negotiated.

\section{Housing is Political}

The invention of type-furniture (Typenmöbel), a piece of furniture designed for serial production and versatile in its reduction to its basic function (Rüegg \& Tropeano, 1995), proved key to the development of a new living concept: type-furniture as the embodiment of a modern way of living, because it gives an answer to the question of how to live in order to develop a new attitude to life. Modern individuals, as it was envisioned, no longer purchased a complete set of furniture at the beginning of their adult life, but instead supplemented it according to their needs and stage of life. Flexibility, lightness and effectiveness were the principles along which typefurniture was to be designed. Apartments would become lighter and less time-consuming, granting their residents more time for relaxation and self-development: 
The practicality of the organization of the space and the form and nature of the furniture is suited to give the gainfully employed person, who in the haste of our work pace consumes himself more and faster, a greater measure of rest, relaxation and recreation, through the comfort provided by simple means and through the linear harmony [of the furniture's design], which has a calming effect on human beings. (St. Galler Tagblatt, 1930a)

The workers' newspaper Das Volk argued more militantly. It was the working class in particular which could benefit from the housing reform, as the author of this article writes. Because above all they were the ones suffering under modern production conditions and were increasingly exploited through "accelerated production speed" and "intensified rationalization" (Das Volk, 1930). The home as a space of leisure and recovery thus became an urgent issue in workers' class struggles:

In dull, grey, lightless tenements, in the midst of uncomfortable furniture that seeks to appear 'noble' by the poorest means: in such an environment selfconfidence and proletarian power simply cannot unfold; this is the right milieu to force the worker into resignation, to hold him down in dullness and mental dependence. (Das Volk, 1930)

On the subject of furniture, the question of the appropriate contemporary, modern way of living was being negotiated-not just for the working class. Apartment and furniture were to be a unit, a complementary overall concept, tailored for the life of the modern individual in general. The development of new housing should be based on the furniture itself and not the other way around. Whereas type-furniture was considered as a gateway to modern life, the petit bourgeois household with its curtains, decorative blankets, vases and especially the parlour (gute Stube), in contrast, became an object of ridicule (Janser, 2001).

In the Swiss press discourse on the 'Woba', there was no agreement on whether the residential colony was a success, and whether it was the appropriate solution for future housing. Whereas Das Volk praised the plain design of the furnishings in particular because it would fit in well with the hard sobriety of a workers' life (Das Volk, 1930), an article in the newspaper Der Bund criticized the "mini-size apartment" (Der Bund, 1930). Is the Eglisee residential colony really the only solution and should architects approach modern housing only from an economic point of view, it asks. The author's lamentation of the monochrome and monotonous colour palette and the lack of space for personal belongings, refers to two closely related discussions. The first touches the question of aesthetics and already gives an idea of the Heimatstil debate coming to its full height during the 1930s. It was less the flat roof, as one would expect, but rather the uniformity of these houses, the monotonous colour scheme and the standardized doors and windows, which did not quite fit the Swiss landscape. "In the future, should these mundane buildings provide foreigners coming from the north with their first impressions of Switzerland?", asked a visiting journalist from the Emmenthal. "Our solid and beautiful architecture [Bauart] should not be replaced by this foreign living machine [Wohnmaschine], because our house is still our home" (A. V., 1930). This leads us to the second discussion, which took up much more space than the question of aesthetics. The author of the above-mentioned article in Der Bund, further stated: "Yet that is the family's sore spot. After all, what good is the cleanest living machine [Wohnmaschine] if the individual is not encouraged by being somewhat himself?" (Der Bund, 1930). The St. Galler Tagblatt went even further by stating that the houses' extreme, oppressive narrowness would ultimately lead to a breakdown of the family unit (St. Galler Tagblatt, 1930b). Marcel Pilet-Golaz, Member of the Federal Council and President of the Honorary Committee of the 'Woba', pointed right at it when he wrote in 1930:

The apartment-the home-is the foundation of family life, and is the family not the germ cell [Grundzelle] of human society? Society is nothing more than what families are, and families, in turn, are what womenhonor where honor is due-and peoples' homes have made of them. (Schweizer Gewerbezeitung, 1930)

As these statements show, a strong connection has been made between the well-being of the family and society as a whole. The development of a person's individuality proved key to this concept. The home, and architecture in general, was thus attributed with a "constituent" quality: individuals were formed by their environment, by the milieu they live in. This semantic change was a specific feature of modernity, as Makropoulos (2003) describes it. Architecture was no longer thought of as having a representative function, but as a "constitutive medium of social reality" (Makropoulos, 2003, p. 577). The conservative voices in the Swiss press discourse were therefore worried that if this home, the "germ cell" of society, no longer grants people a sense of security, no longer educates them to individuality and personality, but promotes "egalitarianism" - understood as synonymous to collectivization in a socialist or communist sense-then the entire social fabric is at the risk of collapse:

If someone lets his individuality be completely replaced by 'class consciousness', he will lose the ability of making his own judgements....Whoever contemplates the complete egalitarianism which reigns both in the terraced houses and in the single-family houses here [in the Eglisee colony], will almost inevitably feel the spiritual monotony, the lack of any personal feeling and experience, like a heavy burden on his conscience....Is there still the possibility of a family life in such an apartment?...Cliché-apartment, which will 
have lost its homeliness after a short time of use! This is the ideal of the Marxist 'housing culture' [marxistische 'Wohnkultur'], the 'communal ideal', which finds its greatest impact in trade union and party....The unity of the family will be systematically destroyed and replaced by the communist ideal. These housing colonies provide the means for it. (Solothurner Zeitung, 1930)

The discussion in the press was fuelled by the article "Individualistische oder Sozialistische Wohnkultur?" appearing in mid-August 1930 in Volksrecht, a social democratic trade union newspaper. Its author rejected the idea of the garden city as a bourgeois dream of the villa in the park and instead called for the construction of residential complexes with public service features, concluding that, in the field of housing culture, the individualistic principle had to be gradually replaced by the socialist principle (Volksrecht, 1930). A different article took up this argument: "Today's question is: Individualistic or socialist housing ideal! Under the pretense of housing costs and housing comfort, the flattening of people's minds, and the depersonalization of the individual is being promoted". Socialists and "their comrades in arms, the communists" (G. H., 1930) would demand communal housing solutions to forge their political agenda. "As we can see, the question of housing culture should-according to the red brothers-be solved in such a way that the individual housing principle is being transformed into a collective, Marxist-socialist one by means of standardized furnishing". (G. H., 1930). He continues: "Some see it as the style to come, others as a work of Bolshevism that exploits the influence of buildings on people in the sense of depersonalization" (Schweizerische Arbeitgeber-Zeitung, 1930). The author of the article in the Schweizer Gewerbe Zeitung struck the same chord, but concluded that there is little to fear, as the brave Swiss housewife and daughter do not let themselves be "depersonalized" so easily (G. H., 1930).

The fact that women played an important role in the design of the family home was reflected in various press articles concerning the 'Woba'. The apartment exerts a decisive influence on women's character and emotions, one author contended (Aargauer Tagblatt, 1930). Particularly in discussions of the innovations of the "kitchen diner" (Wohnküchen) and rationalized small kitchen, the use of the housing reform for women was brought up. Financial hardship in working families leads to multiple burdens for women, it was observed: women would work for eight hours, and also have to do the chores when they come home:

This makes it all the more important that the workers' apartment is designed to be as labour-saving as possible: the woman should not devote all her free time to housework, but should instead be able to relax or at least find time for her children. In other words: small and simple furniture that does not cause much work, a small kitchen, a dining room in very close proximity to the kitchen, in order to prevent excessive walking around but still to avoid living in the kitchen (which is not a living room, but a working room). (Das Volk, 1930)

Another article focuses on the aspect of housework as work in particular. Since the housewife considers her work to be her profession, her workplace must be designed according to the principles of rationalization. Basically, kitchen work can also represent a "production line", in which the "tools" are arranged practically in the smallest space so that the work can be carried out "as effortlessly and quickly" as possible (Luzerner Neueste Nachrichten, 1930). The idea of Taylorization and rationalization had left the factories and entered the private home. Surprisingly, the press coverage did not refer to the famous Frankfurter Küche invented by Margarete Schütte-Lihotzky in 1926. Rather, it referred to the exhibition in the Gewerbemuseum in Basel earlier the year on the "the practical kitchen" (Die praktische Küche, February and March 1930) and the SAFFA exhibition on women's work in 1928. In one article, the author highlights the fact that despite the construction law of Basel, which does not allow rooms smaller than eight square meters, rationalized standard kitchens were being installed in the 'Woba' houses. This refers to an oftenoverlooked aspect prominently discussed at the II CIAM congress. The main obstacles for the realization of minimized and standardized houses were the outdated construction laws, which did not keep up with the new construction possibilities. That is why much effort was put into this rather dry technical aspect. Schmidt argued in several articles that the task of creating the new "rational minimal housing" (rationelle Kleinwohnung) could only be solved in a cost-effective way if existing construction laws and standards were amended (Schmidt, 1929).

The article "Marriage Avoidance and Housing Reform" (Eheflucht und Wohnungsreform), written by the 'Woba' press committee itself, built on the earlier argument by Pilet-Golaz. As the title implies, "marriage avoidance" was a legitimate point of consideration in the design of the modern living unit. Many women, especially the "so-called 'modern' ones...choose the freedom of living alone" over marriage, which, as the author stated, was not to be blamed on women alone, because:

Today's marriage asks too much of the woman. She ought to be a homemaker, possibly a mother andsince the costs of living require it-also working at the same time. Is such versatility ever required of a man? No. He is an earner-outside the home-but an earner only. He does not have to split his powers into a thousand things. (Eheflucht und Wohnungsreform, n.d., p. 1)

If marriage is to become more appealing to women again, then housing must be simplified. Superfluous things 
like the parlour should be abolished, dust-collecting ornaments replaced by smooth surfaces, and a practical small kitchen should be provided for quick cooking. All in all, a small apartment would reduce the amount of work, and thus have a positive effect on married life in particular. "The new way of living does not know a worn-out woman; a worn-out woman is always in a bad mood, she does not tie a man to herself" (Eheflucht und Wohnungsreform, n.d., p. 2). Although the article sounds rather progressive, there was no discussion about freeing women from housework. Rather the opposite was intended: a woman's place is in the kitchen, even if it is a rationalized and standardized one. That is where she should carry out her civic duty and contribute efficiently to the stability of modern society-by providing families with functional homes.

As shown, various discourses can be tracked down in the Swiss press coverage of the 'Woba' and they all lead to the question of the form, nature and needs of modern society. On one side stood the idea of the unity of state, family and nation, on the other the unity of party, community and class. The will to reshape society through architecture and interior design expressed by the supporters of Neues Bauen was a provocation to many, who saw a communist scheme at work in their efforts at standardization, rationalization and minimization. In his programmatic article Das Bauen ist nicht Architektur published in 1927, Hans Schmidt had already proclaimed that building was no longer to be art, but a social task waiting for a solution (Schmidt, 1927, p. 139). ABC Beiträge zum Bauen, a Swiss avant-garde architecture magazine co-edited by Schmidt, was framed by the two slogans " $A B C$ demands the dictatorship of the machine" and "ABC fights against the bourgeois era" (Schmidt, Stam, Lissitzky, \& Roth, 1927, pp. 1, 12). To Schmidt, the question was not what kind of house was built, but rather, what kind of society. Conservative forces accusing Neues Bauen and the political left of "egalitarianism" had correctly identified their opponents' goal: the break-up of the existing order and the creation of a new society. The little man, the worker, men and women - that was the future. Class differences were to be overcome in favour of social justice.

Indeed, the leftist architectural modernists were looking eastwards to achieve this goal. At the same time in Soviet Russia, far more extreme proposals were discussed than in Switzerland. The idea of the dom kommuny, the so-called communal houses intended to accustom people to a collectivized life, were starting to be built by the end of the 1920s. The most famous example was the so-called Narkomfin communal building. The architectural structure of the house and the spatial design was supposed to encourage its inhabitants to become accustomed to a collectivized lifestyle by providing them with a communal kitchen, laundry and a nursery, where their children lived and were brought up by professionals. The complex also included a library and sports hall for the New Man's physical and mental cultivation (Buchli, 2000; Cramer \& Zalivako 2013). Because of Soviet
Russia's pioneering task, the IV CIAM Congress was to take place in Moscow in 1932. Due to the outcome of the competition for the Palace of the Soviets, in which a classicist building won first place, the congress was postponed and instead held one year later on a cruise ship on its way to Athens. This event was a huge disappointment for the international modern avant-garde and made clear in which direction Soviet Russia was heading as a result of Stalinist cultural revolution.

At the end of the 'Woba', Hans Schmidt published an article with the title Arbeiterwohnungen (Schmidt, 1930c) in the communist-oriented newspaper Basler Vorwärts. Schmidt expressed an extremely critical attitude towards the 'Woba' and drew a gloomy conclusion. The problem of workers' housing, Schmidt wrote, were of the same kind as other problems that one tried to solve "on the ground of today's order". "As long as the workers' apartment remains the 'workers' apartment", Schmidt argued, "and not the apartment for everyone, all efforts in this area will be in vain". The housing question should be understood as an "expression of general necessity" and should therefore be given top priority. The dream of a small detached house was a petit bourgeois ideal, not a worker's ideal, and the entire housing question continues to be solved without the worker in mind. "One won't stop solving the housing question of the worker in a petty bourgeois sense until one really makes an effort to know what the modern worker actually needs for living" (Schmidt, 1930c). If conservative forces asserted that a Russian worker's living standard was not even close to the one of a Swiss worker, they should bear in mind that Russia had "acknowledged the task of creating appropriate living and working conditions for an entire society by the means of a systematic approach" (Schmidt, 1930c). By the time Hans Schmidt published these reflections, he already knew that in no less than four weeks he and his family would move to the Soviet Union. Schmidt was not the only one who tried his luck in the East. With the beginning of the first Five-Year Plan in 1928, the Soviet Union engaged many foreign specialists to master the task (Flierl, 2012; Muscheler, 2016; Suter, 1993).

Schmidt and his colleagues were convinced they could change workers living conditions by providing them with good housing. Their self-understanding was very much tailored by a top down perspective on society's problems, a phenomenon described as "social engineering" (Etzemüller, 2009). Etzemüller highlights that exactly this fetishization of order through standardization and rationalization served as metaphors for a functioning society. It was not only a matter that was addressed by the social planning experts, but also discussed broadly and controversially in the general public.

\section{Conclusions}

During the 'Woba', socio-political discourses gained concrete shape in the form of the housing question. On the 
one hand, there was the left architectural avant-garde, who conceived of their construction program as a social necessity. On the other hand stood conservative forces, who perceived this kind of architecture as a threat to the social order. The Heimatstil debate and the question of Baubolschewismus, which shaped the reception of this project, had already been underway previously, as much as the Neues Bauen (Dogramaci, 2019; Kohlrausch, 2019), influenced by developments in neighboring countries. Despite claims to a greater international outlook, the German scene remained the main point of reference for Switzerland's architectural avant-garde, and developments in other countries received comparatively little attention (Kuchenbuch, 2010; Rudberg, 1999).

Taking cues from abroad, the Swiss discourse on Neues Bauen also spilled over the borders of the federation. The pamphlet "The Architecture Crisis" (Krisis der Architektur), published in 1928 by Swiss architect Alexander von Senger (1928), proved foundational for the introduction of racist notions into the international discussion on Neues Bauen. With this publication, Von Senger, who regarded the movement as disguised communist propaganda controlled by Moscow, popularized the term Baubolschewismus-bolshevism by architecture (Blümm, 2013, p. 25)-which later gained notoriety especially in Nazi Germany. Racist notions soon also became pervasive in Switzerland itself-not least at the 'Woba', which Marcel Pilet-Golaz opened with a passionate speech praising "will, drive and endurance" as inherent qualities of the Swiss people, which prevailed despite war and political upheavals. "These are racial characteristics [Rassenmerkmale]!", Pilet-Golaz declared, "thanks to them there's hope, and through them we will succeed" (Schweizer Freie Presse, 1930).

The discussions that surrounded Neues Bauen in Switzerland, for example on the occasion of the competition for the Kunstmuseum Basel (Birkner, 1995, p. 22; Heim, 2016) and the exhibition in the Werkbundsiedlung Neubühl in 1932 (Marbach \& Rüegg, 1990, p. 46), have so far been studied exclusively as specialist discourses within architectural circles (Schnell, 2005). Yet, Neues Bauen resonated far beyond the architectural scene, evoking strong reactions from all sides of the political spectrum. In 1930, the year the 'Woba' took place, political radicalization in Switzerland and all of Europe had intensified sharply. The political left was deeply fractured, the conservatives unwilling to give up their positions and, in addition to the fear of the 'red plague', National Socialism and Italian fascism gained more and more adherents. My analysis of press coverage on the 'Woba' has shown that the discussion of the architecture and interior design of the Eglisee residential colony was inseparable from such larger social conflicts. The question of what the apartment of the future should look like was closely tied to the question of where the future society should be heading towards. The polarized reception of the 'Woba' reflected the increasingly fractured state of society itself.

\section{Acknowledgments}

I would like to thank Muriel Pérez (gta Archiv, Zürich), Lukas Gruntz und Klaus Spechtenhauser (www.ein-hauswoba.ch), as well as my co-workers at the Chair for Eastern European History, University of Basel, who discussed this text at an early stage. I am particularly grateful for the English language editing that was carried out by Melissa Frost and the critical and fruitful commenting of my text by Markus Bardenheuer.

\section{Conflict of Interests}

The author declares no conflict of interests.

\section{References}

Aargauer Tagblatt. (1930, September 10). Die Frauen an der Woba [Women at the Woba]. Aargauer Tagblatt.

Artaria \& Schmidt Architekten. (1928, August 9). Siedlung Schorenmatten [4 plans]. Nachlass Hans Schmidt (61-070, M. A1). Archiv des Instituts für Geschichte und Theorie der Architektur (gta), Zurich.

A. V. (1930, September 6). Die Siedlung Eglisee an der Woba [The Eglisee residential colony at the Woba]. Emmenthaler Blatt.

Baukommission der Schweizer Wohnungsausstellung Basel 1930 (1929, February 26). Protokoll zur Sitzung vom Dienstag 26. Februar 1929. [Minutes of the meeting of Tuesday 26 February 1929]. Schweizerische Wohnungs-Ausstellung WOBA in Basel 1930 (Ausstellungen B 29). Staatsarchiv des Kantons BaselStadt, Basel.

Baukommission der Schweizer Wohnungsausstellung Basel 1930 (n.d.). Wohnkolonie. [construction schedule]. WOBA: Schweizerische Wohnungsausstellung, Basel (1930) (Prospekte Ausstellungsführer, Ausstellungen B 77). Schweizerisches Wirtschaftsarchiv, Basel.

Birkner, O. (1995). Die gute Form: Leitbild bürgerlicher Lebensqualität. Deutschweiz zwischen Bauhaus und Nationalsozialismus [The good form: A model of middle-class living quality. German-speaking Switzerland between Bauhaus and National Socialism]. In A. Rüegg \& R. Tropeano (Eds.), Wege zur "Guten Form": Neun Beiträge zur Geschichte der Schweizer Produktgestaltung [Ways to a "good form": Nine contributions on the history of Swiss product design] (pp. 20-25). Basel: Birkhäuser.

Blümm, A. (2013). "Entartete Baukunst"? Zum Umgang mit dem Neuen Bauen, 1933-1945. Schriften der Berliner Forschungsstelle "Entartete Kunst" ["Degenerate architecture"? On the handling of the Neues Bauen, 1933-1945. Writings of the Berlin research centre "degenerate art"]. München: Wilhelm Fink Verlag.

Buchli, V. (2000). The Narkomfin communal house and the material culture of socialism. In V. Buchli (Ed.), An 
archaeology of socialism (pp. 63-76). Oxford: Berg.

Bürkle, J. C., \& Eidgenössische Technische Hochschule Zürich. (1994). Die Rotach-Häuser: ein Prototyp des Neuen Bauens in Zürich: "die Musterhäuser an der Wasserwerkstrasse" von Max Ernst Haefeli [The Rotach Houses: A Prototype of the Neues Bauen in Zürich: 'The Show Homes at the Wasserwerkstrasse' by Max Ernst Haefeli]. Zurich: gta.

Cramer, J., \& Zalivako, A. (Eds.). (2013). Das NarkomfinKommunehaus in Moskau (1928-2012): Das Haus des Volkskommissariates für Finanzen $=$ Dom Narkomfina [The Narkomfin communal house in Moscow (1928-2012): The house of the people's commissariat for finance $=$ Dom Narkomfina]. Petersberg: Imhof.

Das Volk. (1930, September 6). Wohnkolonie Eglisee und Arbeiterschaft [The Eglisee residential colony and the working class]. Das Volk.

Der Bund. (1930, August 27). Das Bauen an der Woba [Building at the Woba]. Der Bund.

Dogramaci, B. (2019). Akteure, Konzepte und Objekte in Bewegung: Transferprozesse in der Architekturgeschichte der Moderne [Actors, concepts and objects on the move: Transfer processes in the history of modern architecture]. In J. Stabenow \& R. Schüler (Eds.), Vermittlungswege der Moderne: Neues Bauen in Palästina (1923-1948) [The transfer of modernity: Architectural modernism in Palestine (1923-1948)] (pp. 37-49). Berlin: Gebr. Mann Verlag.

Eheflucht und Wohnungsreform. (n.d.) Eheflucht und Wohnungsreform [Marriage avoidance and housing reform]. [draft]. Archiv Schweizerische Wohnungsausstellung in der Basler Mustermesse 1930 (Zeitungsartikel bzw. Entwürfe zu den Communiqués, $\mathrm{CH}$ SWA HS $141 \mathrm{~S}$, Blatt 21). Schweizerisches Wirtschaftsarchiv, Basel.

Etzemüller, T. (Ed.). (2009). Social engineering als Verhaltenslehre des kühlen Kopfes. Eine einleitende Skizze [Social engineering as behavioural theory of the calm mind. Introductory thoughts]. In T. Etzemüller, (Ed.), Die Ordnung der Moderne: Social Engineering im 20. Jahrhundert [The Order of Modernity: Social Engineering in the 20th Century] (pp. 11-39). Bielefeld: transcript-Verlag.

Flierl, T. (Ed.). (2012). Standardstädte: Ernst May in der Sowjetunion 1930-1933: Texte und Dokumente [Standard cities: Ernst May in the Soviet Union 1930-1933: Texts and documents]. Berlin: Suhrkamp.

G. H. (1930, August 30). Leserbrief [Letter to the editor]. Schweizer Gewerbe Zeitung, Zurich.

Gruntz, L. (2016). WOBA 1930. Das neue Wohnen in Basel. Teil I [The New Housing in Basel, Part I]. Basel: FHNW School of Architecture, Civil Engineering and Geomatics.

Gruntz, L. (2017). WOBA 1930. Das neue Wohnen in Basel. Teil II [The New Housing in Basel, Part II]. Basel: FHNW School of Architecture, Civil Engineering and Geomatics.
Heim, C. (2016). Basel und sein Kunstmuseum: Der Hang zum Monumentalen [Basel and its art museum: A fascination for the monumental]. Basler Stadtbuch. Retrieved from https://www.baslerstadtbuch.ch/ dossier/2016/basel-und-sein-kunstmuseum.html

Janser, A. (2001). Hans Richter, die neue Wohnung: Architektur, Film, Raum [Hans Richter, the New Housing: Architecture, film and space]. Baden: Lars Müller Publ.

Kienzle, H. (1926, December 29). Brief der Direktion des Gewerbemuseums Basel an den Vorsteher des Departements des Innern, Herrn Regierungsrat G. Wenk. Betr. Raumkunstausstellung 1927 in der Mustermesse. [Letter from the Directorate of the Gewerbemuseum Basel to the Head of the Department of the Interior, G. Wenk. Concerning the Raumkunstausstellung 1927 in the Mustermesse]. Schweizerische Wohnungs-Ausstellung WOBA in Basel 1930 (Ausstellungen B 29). Staatsarchiv des Kantons Basel-Stadt, Basel.

Kohlrausch, M. (2019). Brokers of modernity: East Central Europe and the rise of modernist architects, 1910-1950. Leuven: Leuven University Press.

Kuchenbuch, D. (2010). Geordnete Gemeinschaft: Architekten als Sozialingenieure: Deutschland und Schweden im 20. Jahrhundert [Ordered community: Architects as social engineers. Germany and Sweden in the 20th century]. Bielefeld: transcript-Verl.

Luzerner Neueste Nachrichten. (1930, August 12). Die praktische Küche [The practical kitchen]. Luzerner Neueste Nachrichten.

Makropoulos, M. (2003). Vergesellschaftung durch Architektur: Gesellschaftstheoretische Aspekte der funktionellen Stadt [Socialization through architecture: Social theoretical aspects of the functional city]. In J. Fischer \& H. Joas (Eds.), Kunst, Macht und Institution. Studien zur Philosophischen Anthropologie, soziologischen Theorie und Kultursoziologie der Moderne [Art, power and institution. Studies in philosophical anthropology, sociological theory and cultural sociology of modernity.] (pp. 577-586). Frankfurt am Main: Campus.

Marbach, U., \& Rüegg, A. (Eds.). (1990). Werkbundsiedlung Neubühl in Zürich-Wollishofen 1928-1932: Ihre Entstehung und Erneuerung. Dokumente zur modernen Schweizer Architektur [The Werkbundsiedlung Neubühl in Zurich-Wollishofen 1928-1932: Its origin and renewal. Documents on modern Swiss architecture]. Zurich: Gta Verlag.

Mooser, J. (2000). Konflikt und Integration: Wirtschaft, Gesellschaft und Politik in der 'Wohlfahrtsstadt' [Conflict and integration: Economy, society and politics in the 'welfare city']. In G. Kreis \& B. v. Wartburg (Eds.), Basel: Geschichte einer städtischen Gesellschaft [Basel: The history of an urban society] (pp. 226-263). Basel: Christoph Merian Verlag.

Muscheler, U. (2016). Das rote Bauhaus: Eine Geschichte von Hoffnung und Scheitern [The red Bauhaus: A 
story of hope and despair]. Berlin: Berenberg.

Ochs-Walde (1930). The 'Woba' residential colony eglisee, 1930. Block 10, Hans Bernoulli, August Künzel. From the garden. Basel: Archiv Wohngenossenschaft Eglisee.

Pilet-Golaz, M. (1930, August 30). Politik und Wohnung [Politics and housing]. Schweizer Gewerbezeitung.

Pläne der Wohngenossenschaften Lange Erlen. (1928, January 25). Pläne der Wohngenossenschaften Lange Erlen und Rüttibrunnen zur Überbauung des Gutes Alois Stebler-Zurkirchen, Schorenweg 1, am Gotterbarmweg (Im Surinam), Basel [Plans for the housing cooperatives Lange Erlen and Rüttibrunnen for the development of the Alois Stebler-Zurkirchen estate]. Verbandsarchiv Schweizerischer Verband für Wohnungswesen und Wohnungsreform (CH SWA HS 180 E'). Schweizerisches Wirtschaftsarchiv, Basel.

Pola, M., \& Frischknecht, J. (Eds.). (n.d.). Hans Bernoulli: Siedlung "Im Vogelsang" [Hans Bernoulli: Residential colony "Im Vogelsang"]. Basel: Staatsarchiv BaselStadt.

Rudberg, E. (1999). The Stockholm exhibition 1930: Modernism's breakthrough in Swedish architecture. Monographs published by the city of Stockholm. Stockholm: Stockholmia Förlag.

Rüegg, A., \& Tropeano, R. (Eds.). (1995). Wege zur "Guten Form": Neun Beiträge zur Geschichte der Schweizer Produktgestaltung [Ways to a "good form": Nine contributions on the history of Swiss product design]. Basel: Birkhäuser.

Schmidt, H. [presumably] (n. d.) Billige Wohnungen? [Cheap housing?]. [draft]. Archiv Schweizerische Wohnungsausstellung in der Basler Mustermesse 1930 (Zeitungsartikel bzw. Entwürfe zu den Communiqués, CH SWA HS 141 S, Blatt 3). Schweizerisches Wirtschaftsarchiv, Basel.

Schmidt, H. (1927). Das Bauen ist nicht Architektur [Building is not architecture]. Das Werk, 14(5), 139-153.

Schmidt, H., Stam, M., Lissitzky, E., \& Roth, E. (1927). ABC: Beiträge zum Bauen [ABC: Contributions to building]. New York, NY: Princeton Architectural Press.

Schmidt, H. (1929, April 12). Baugesetzliche Erleichterung für die Projektierung der Wohnkolonie [Building law facilitation for the planning of the housing colony]. Nachlass Hans Schmidt (61-081-Dok-1). Archiv des Instituts für Geschichte und Theorie der Architektur (gta), Zurich.

Schmidt, H. (1930a, August 21). Können wir billige Wohnungen bauen? [Can we build cheap housing?]. National-Zeitung.

Schmidt, H. (1930b, September 4). Kunterbuntes über die WOBA-Siedlung [This and that about the Woba residential colony]. National-Zeitung.

Schmidt, H. (1930c, September 15). Arbeiterwohnungen [Workers' housing]. Basler Vorwärts.

Schmidt, H. (1965). Aufgabe und Verwirklichung der Minimalwohnung, 1929. Entwurf zu Thesen zum II. Kongreß der CIAM Frankfurt a. M. 1929 [Task and realisa- tion of the minimal apartment, 1929. Draft for theses for the II Congress of CIAM Frankfurt a. M. 1929]. In B. v. Flierl (Ed.), Beiträge zur Architektur, 1924-1964 [Contributions to architecture] (pp. 50-52). Basel: Pfalz-Verlag.

Schnell, D. (2005). Bleiben wir sachlich! Deutschschweizer Architekturdiskurs 1919-1939 im Spiegel der Fachzeitschriften [Let's be objective! German-Swiss architectural discourse 1919-1939 in the mirror of trade journals]. Basel: Schwabe.

Schnetzler, K. (2005, November 26/27). Koloniales Basel oder Der Traum von Surinam [Colonial Basel or the dream of Surinam]. NZZ, 277, 81-83.

Schweizerische Arbeitgeber-Zeitung. (1930, August 23). Nachdenkliches zur Woba [Reflections on the Woba]. Schweizerische Arbeitgeber-Zeitung, 34.

Schweizer Freie Presse. (1930, August 23). Bundesrat Pilet an der 'Woba' [Federal Council Pilet at the 'Woba']. Schweizer Freie Presse, Baden.

Senger, A. v. (1928). Krisis der Architektur [The architecture crisis]. Zurich: Rascher \& Cie. A.-G.

Siedlung Schorenmatten, 1929, and WOBA-Siedlung Eglisee, 1930. (1930). [Photograph]. Archiv Wohngenossenschaft Eglisee, Basel.

Solothurner Zeitung. (1930, August 28). Vom 'Neuen Bauen' [About 'Neues Bauen']. Solothurner Zeitung.

Spreng, R. (1930). The 'Woba' residential colony Eglisee, 1930. Block 8, Artaria \& Schmidt Architects. Bedroom, upper floor. Basel: Archiv Wohngenossenschaft Eglisee.

St. Galler Tagblatt. (1930a, August 18). Die Woba in Basel [The Woba in Basel]. St. Galler Tagblatt.

St. Galler Tagblatt. (1930b, August 23). Einzelheiten von der Woba [Particularities on the Woba.]. St. Galler Tagblatt.

Steinmann, M. (Ed.). (1979). Geschichte und Theorie der Architektur. CIAM: Internationale Kongresse für Neues Bauen: Dokumente 1928-1939 [History and theory of architecture. CIAM: International Congresses for Neues Bauen. Documents 1928-1939]. Basel: Birkhäuser.

Suter, U. (Ed.). (1993). Hans Schmidt: 1893-1972: Architekt in Basel, Moskau, Berlin-Ost. Dokumente zur modernen Schweizer Architektur [Hans Schmidt: 1893-1972. Architect in Basel, Moscow, East Berlin. Documents on modern Swiss architecture]. Zurich: gta.

Volksrecht. (1930, August 13). Individualistische oder sozialistische Wohnkultur? [Individualistic or socialist housing culture?] Volksrecht, 188.

Woba. (1930). Woba: Führer durch die AusstellungsSiedlung Eglisee (Prospekte Ausstellungsführer, Ausstellungen B77) [Woba: Guide through the Eglisee housing exhibition (Exhibition Guide Brochures, Exhibitions B77)]. Basel: Schweizerisches Wirtschaftsarchiv.

Wohnbaugenossenschaften Nordwestschweiz. (2012). Wohngenossenschaften der Region Basel 1992-2012: 
Ein Projekt zum UNO-Jahr der Kooperativen [Housing cooperatives in the Basel region 1992-2012: A project for the UN year of coopera- tives]. Basel: Wohnbaugenossenschaften SchweizNordwestschweiz.

\section{About the Author}

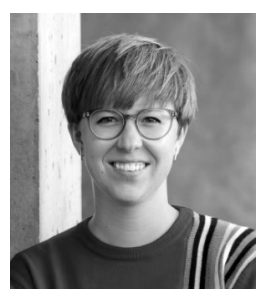

Rhea Rieben (MA) is a Research Assistant and PhD student at the University of Basel (Department of History). She graduated in Slavonic Studies and Eastern European History at the University of Basel and the Higher School of Economics in Moscow. She specializes on modern Soviet and European architecture, Swiss-Soviet relations and the project of modern society. Her current research project is on Swiss architect Hans Schmidt and his participation in the five-year plans of the USSR during the 1930 s. 